\title{
Experience of applying and integrating of the online education system on a base of Moodle platform into the university's educational environment
}

\author{
Slavko G. ${ }^{*}$, Serhiienko S. \\ Kremenchuk Mikhailo Ostrogradskyi National University, Kremenchuk, Ukraine
}

\begin{abstract}
Received: 01.04 .2019
Accepted: 15.04 .2019

Abstract. The growth of the number of alternative sources of quality knowledge and ways of obtaining them by information and media Internet technologies creates a rivalry between traditional educational institutions in the educational space and prompts the usage of modern teaching methods. Implementation of Internet information technologies in higher education institutions faces a number of problems due to the lack of sustainable methods and the diversity of curricula, in particular, the need for teachers to acquire relevant competencies and the need to change teaching paradigms. In addition, online education systems, despite their benefits, such as the dynamism of educational material updates, accessibility and transparency, have certain disadvantages that require comprehensive study and adaptation to the regulatory requirements of the education system. Even though there are separate control documents in Ukraine, that define the terminology and basic principles of distance learning, e-learning textbooks and courses, etc., the latest on-line technologies need the accumulation of practical experience and comprehensive study of methods for the implementation, use and development of relevant software in accordance with educational standards. The article analyzes and summarizes the experience of construction of the online education system on the Moodle platform by the example of Kremenchuk Mykhaylo Ostrogradsky National University. Recommendations on optimization of the implementation process are given in the article. Also this article identifies main problems of integrating the online system into the educational space of the educational institution and ways of their solution. Authors have proposed a methodology of deployment of the online education system, have investigated the possibility of taking into account priorities of users and peculiarities of educational disciplines during its modular sequential configuration. Authors have analyzed the dynamics of educational materials addition and have developed software for statistical analysis of quantitative characteristics of electronic training courses in order to optimize the costs of implementation. The article confirms that the use of online education system helps to improve the quality of educational services and reduces costs of software through the use of online technologies.
\end{abstract}

Key words: distance education, e-learning course, testing, evaluation criteria, sql-queries, certification.

\section{Досвід упровадження та інтеграції системи онлайн-навчання на платформі Moodle у освітній простір університету}

\author{
Славко Г. В., Сергієнко С. А.
}

Кременчуцький національний університет імені Михайла Остроградського, Кременчук, Україна

\begin{abstract}
Анотація. Збільшення кількості альтернативних джерел якісних знань і способів їх отримання із застосуванням інформаційно-медійних інтернет-технологій створює конкуренцію традиційним навчальним закладам у освітньому просторі та спонукає до використання сучасних методик викладання. Упровадження інформаційних інтернет-технологій у закладах вищої освіти через відсутність сталих методик і різноманіття навчальних програм стикається з низкою проблем, зокрема, з необхідністю набуття викладачами відповідних компетенцій та потребою у зміні парадигм навчання. Окрім того, системи онлайн-навчання попри свої переваги, такі як динамічність оновлення навчального матеріалу, доступність та прозорість, мають певні недоліки, які потребують усебічного вивчення та адаптації до нормативних вимог системи освіти. I хоча в Україні запроваджуються окремі керівні документи, які визначають термінологію та основні засади дистанційної освіти, електронних навчальних підручників та курсів тощо, новітні онлайн-технології потребують накопичення практичного досвіду та всебічного вивчення методик упровадження та використання й розробки
\end{abstract}

\footnotetext{
Corresponding Author: Slavko Gennadii Volodymyrovych. Tel. +38(05366) 3-21-01. E-mail: krnu@i.ua. Kremenchuk Mykhailo Ostrohradskyi National University, vul.Pershotravneva, 20, Kremenchuk, Poltava Region, Ukraine, 39600.

Bidnoвідальний автор: Славко Геннадій Володимирович.+38(05366) 3-21-01. E-mail: krnu@i.ua. Кременчуцький національний університет імені Михайла Остроградського, вул. Першотравнева, 20, м. Кременчук Полтавської обл., Україна, 39600.
} 
відповідного програмного забезпечення відповідно до освітніх стандартів. У статті проаналізовано та узагальнено досвід побудови системи онлайн-навчання на платформі Moodle на прикладі Кременчуцького національного університету імені Михайла Остроградського, надано рекомендації щодо оптимізації процесу, визначено основні проблеми інтеграції онлайн-системи в освітній простір навчального закладу та шляхи їх розв'язання. Авторами запропоновано методику розгортання системи онлайн-навчання, досліджено можливість урахування пріоритетів користувачів та особливостей навчальних дисциплін під час їі модульного послідовного конфігурування, проаналізовано динаміку наповнення навчальними матеріалами та розроблено програмне забезпечення для статистичного аналізу кількісних характеристик електронних навчальних курсів для оптимізації витрат на упровадження. У статті підтверджено, що використання системи онлайн-навчання сприяє покращенню моніторингу якості освітніх послуг і зменшує витрати на програмне забезпечення завдяки онлайн-технологіям.

Ключові слова: дистанційна освіта, електронний навчальний курс, тестування, критерії оцінювання, sqlзапити, атестація.

\title{
Опыт внедрения и интеграции системы онлайн-обучения на платформе Moodle в образовательное пространство университета
}

\author{
Славко Г. В., Сергиенко С. А. \\ Кременчугский национальный университет имени Михаила Остроградского, Кременчуг, Украина
}

\begin{abstract}
Аннотация. Увеличение количества альтернативных источников качественных знаний и способов их получения за счет информационно-медийных интернет-технологий создает конкуренцию традиционным учебным заведениям в образовательном пространстве и побуждает к использованию современных методик преподавания. Внедрение информационных интернет-технологий в учреждениях высшего образования из-за отсутствия устоявшихся методик и разнообразие учебных программ сталкивается с рядом проблем, в частности, с необходимостью приобретения преподавателями соответствующих компетенций $и$ потребностью в изменении парадигм обучения. Кроме того, системы онлайн-обучения несмотря на свои преимущества, такие как динамичность обновления учебного материала, доступность и прозрачность, имеют определенные недостатки, которые требуют всестороннего изучения и адаптации к нормативным требованиям системы образования. И хотя в Украине вводятся отдельные руководящие документы, определяющие терминологию и основные принципы дистанционного образования, электронных учебников, курсов и т. А., новейшие онлайн-технологии требуют накопления практического опыта и всестороннего изучения методик внедрения и использования и разработки соответствующего программного обеспечения в соответствии с образовательными стандартами. В статье проанализирован и обобщен опыт построения системы онлайн-обучения на платформе Moodle на примере Кременчугского национального университета имени Михаила Остроградского, даны рекомендации по оптимизации процесса внедрения, определены основные проблемы интеграции онлайн-системы в образовательное пространство учебного заведения и пути их решения. Авторами предложена методика разворачивания системы онлайн-обучения, исследована возможность учета приоритетов пользователей и особенностей учебных дисциплин во время ее модульного последовательного конфигурирования, проанализирована динамика наполнения учебными материалами и разработано программное обеспечение для статистического анализа количественных характеристик электронных учебных курсов с целью оптимизации затрат на внедрение. В статье показано, что использование системы онлайн-обучения способствует улучшению мониторинга качества образовательных услуг и уменьшает затраты на программное обеспечение за счет онлайн-технологий.

Ключевые слова: дистанционное образование, электронный учебный курс, тестирование, критерии оценивания, sql-запрос, аттестация.
\end{abstract}

\section{Bcmyn}

Упровадження в освітній простір закладів вищої освіти (3ВО) комп'ютерних інформаційномедійних технологій спонукає до зміни парадигм навчання. Ці зміни ґрунтуються на тому, що навчання стає орієнтованим на певну особистість. Персоналізація темпу навчання, рівня складності навчального матеріалу та навіть змістовне наповнення дозволяють формувати компетенції студента згідно з його особистими пріоритетами та здібностями.

Нові освітні парадигми потребують не тільки упровадження у навчальний процес відповідних програмних засобів, але й набуття учасниками нових для них компетенцій. Ідеться про компетенції тих, хто навчається, і тих, хто навчає. Усталені методики викладання, які існували протягом тривалого часу, для нових умов потребують трансформації та адаптації до можливостей, які надають сучасні методології. 
Викладачам доводиться опановувати нові та одночасно змінювати наявні методики навчання. Такі зміни мають ґрунтуватися на психологічній готовності учасників навчального процесу до упровадження інформаційних технологій, але їх інерційність у сприйнятті нового завдає шкоди та уповільнює опанування нових методик.

Одночасно суттєві зміни відбуваються і у структурі програмного забезпечення, яке використовують у навчальному процесі. Якщо донедавна пріоритетнтми були десктопні програмні засоби [1], такі як MathCad, MatLab, LabView та інші, то сьогодні панують онлайн і хмарні технології [2, 3].

Саме таке веб-орієнтоване програмне забезпечення найкраще сприяє упровадженню дистанційних та онлайн-засобів у навчальний процес. 3'являється можливість отримувати результати виконання завдань і проходження тестування, відслідковувати активність окремих учасників навчального процесу, інтегрувати результати у звітність навчального закладу.

Наведемо приклад можливості веб-застосунків для перевірки викладачем завдань 3 програмування. Якщо раніше студенту необхідно було встановити на власний комп'ютер відповідний компілятор (наприклад, для мови C++ чи Python), написати свій програмний код розв'язку завдання, перевірити його, передати код викладачу, який повинен був повторити всю послідовність дій студента, а потім виставити оцінку і повідомити її студенту, то сьогодні студент самостійно завантажує свій розв'язок на сайт і одразу отримує повідомлення про результати автоматичної перевірки з оцінкою. Викладачу не потрібно витрачати час на перевірку коду, а можна зосередитися на створенні електронних навчальних курсів (ЕНК).

Упровадження систем дистанційного та онлайн-навчання потребує низки організаційних заходів для забезпечення їх ефективного використання, а саме: навчання усіх учасників, змінення методик ведення навчального процесу, інтеграції нових технологій у освітній навчальний простір закладу освіти. Проблеми упровадження у навчальний процес інформаційних технологій досліджувались у роботах багатьох учених [4-12], але вважати ці дослідження вичерпними зарано.

Mema роботи: узагальнити досвід упровадження системи-онлайн навчання в освітній простір закладів вищої освіти, визначити пріоритети та проблеми і шляхи їх подолання.

\section{II Матеріал і методи дослідження}

Для упровадження системи онлайн-навчання у Кременчуцькому національному університеті імені Михайла Остроградського [13] вибрана система LMS Moodle - модульне об'єктно-орієнтоване динамічне навчальне середовище [14]. Обгрунтування такого вибору, порівняльний аналіз з іншими платформами наведено у роботі [15]. Основні можливості, конфігурація та налаштування ядра системи Moodle подані у супровідній документації до системи, викладеній на сайті системи [13].

Зазвичай розробка та упровадження системи онлайн-навчання має такі складові:

1. Програмно-технічна: створення сайту, розміщення на хостингу та розгортання системи, налаштування, додавання плагінів, програмування сайта, наповнення інформацією, апробація системи.

2. Організаційно-методична: розробка інструкцій та документації, проведення навчань 3 викладачами та консультування.

3. Навчально-методична: наповнення системи електронними навчальними курсами (ЕНК), зарахування студентів, моніторинг якості та атестація ЕНК, проведення тестування студентів, складання звітів за результатами тестування.

Якщо перші два етапи упровадження потребували типових дій розробників системи, то третій етап виявився найскладнішим, оскільки мав спиратися на відповідні компетенції усіх учасників системи. Упровадження третього етапу системи онлайн-навчання в освітній процес університету доцільно розпочинати після завершення навчального року, щоб до початку нового навчального року викладачі мали можливість ознайомитися з можливостями системи та керівними інструкціями і розпочати створення ЕНК.

Як показує досвід упровадження та інтеграції системи онлайн-навчання, цей етап потребує значних витрат часу та ресурсів. Запропонована авторами методика й послідовність упровадження та інтеграції системи онлайн-навчання, яка мала на меті оптимізувати цей процес, подана на схемі рис. 1. 


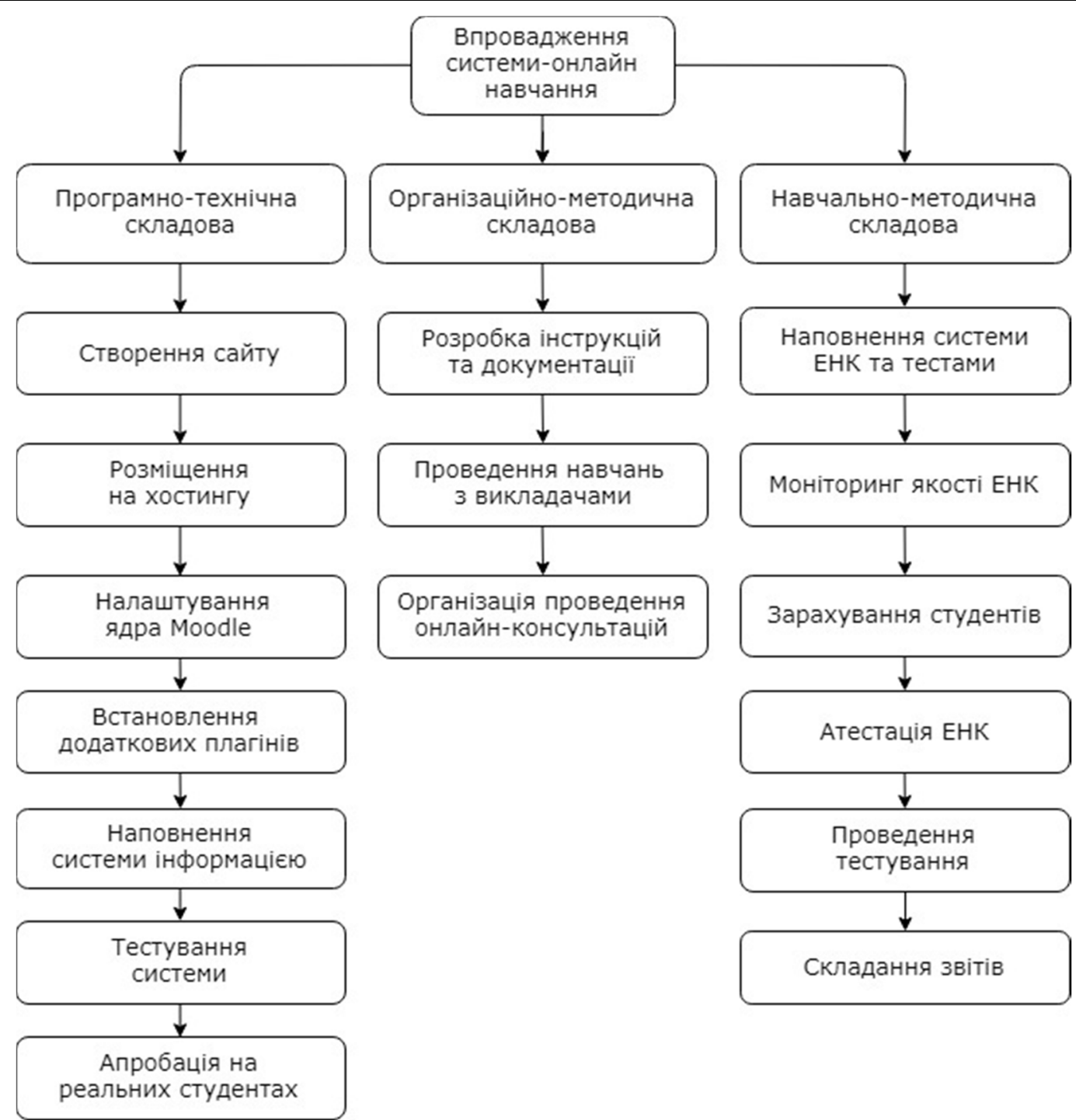

Рис. 1. Запропонована послідовність упровадження системи онлайн-навчання

Для вивчення динаміки упровадження здійснювався моніторинг кількості створених викладачами ЕНК. Для активізації роботи викладачів проводилися семінари з викладачами, були визначені норми часу на виконання робіт з наповнення системи, надані бали за виконання робіт до системи рейтингування викладачів та запроваджена низка адміністративних заходів.

Динаміка збільшення кількості ЕНК і викладачів, які створювали ЕНК подана на рис. 2. Також побудовано лінії трендів з використанням ковзкого-середнього для прогнозування кількості ЕНК та степеневого ряду для кількості викладачів.

Результати прогнозування кількості ЕНК та викладачів використовувалися для оцінювання необхідних хостинг-ресурсів для забезпечення стабільної роботи системи та оптимізації витрат на забезпечення функціонування системи. Окрім того, моніторинг динаміки дозволяв виявляти загальні тенденції та приймати відповідні адміністративні рішення чи проводити додаткові заняття 3 викладачами. Наведені тут залежності можуть бути використані для масштабування на будь-який навчальний заклад, залежно від кількісного складу викладачів та кількості ЕНК, які потрібно створити.

Збільшення загальної кількості ЕНК потребувало автоматизації їх моніторингу, тому були визначені критерії автоматичного оцінювання наповнення ЕНК навчальними матеріалами та розроблені скрипти sql-jquery запитів для плагіна Configurable Reports [14] до Moodle 3.x, що дозволило отримувати автоматичні звіти для подальшого їх аналізу.

Приклад коду такого sql-запиту, який автоматично визначає список ЕНК, до яких додані типові елементи (тести, файли, сторінки, посилання, завдання), наведено на рис. 3. 


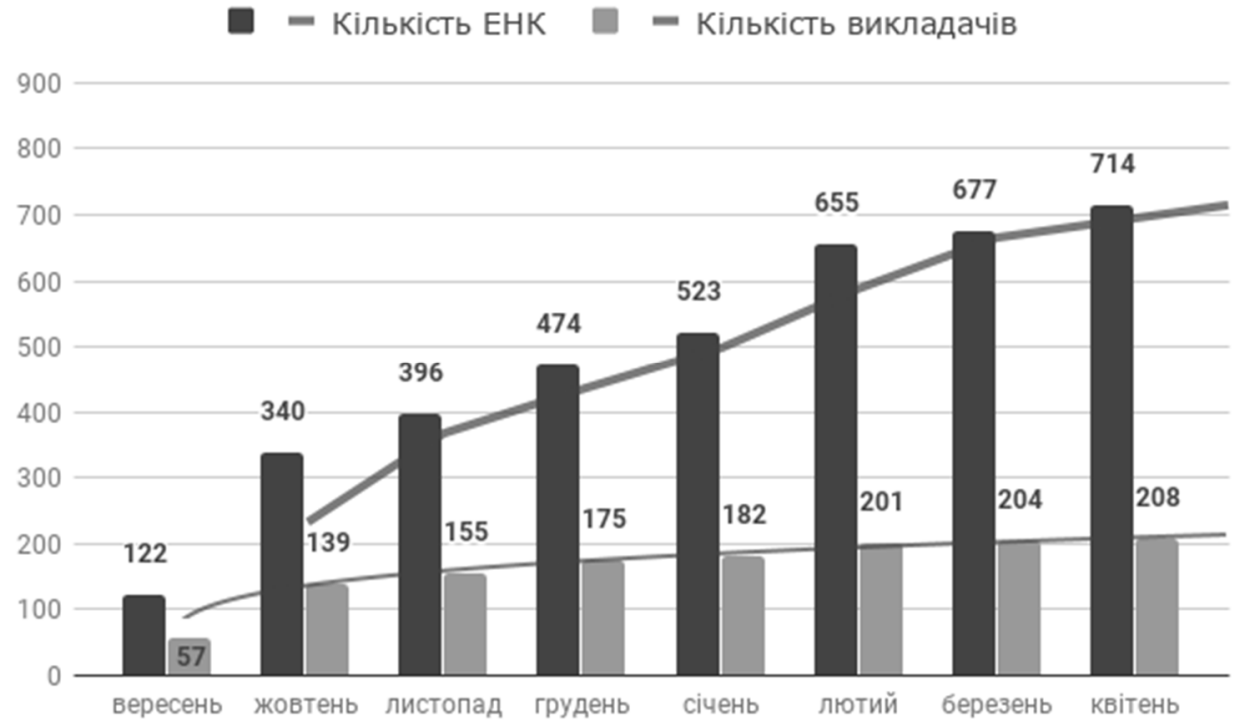

Рис. 2. Динаміка наповнення ЕНК системи онлайн-навчання

SELECT * FROM (

SELECT concat('<a target="_new" href="\%\%WWWROOT\%\%/course/index.php?categoryid=', cc.id,"'>', cc.name, '</a>') AS "Кафедра",

concat('<a target="_new" href="\%\%WWWROOT\%\%/course/view.php?id=',c.id,"'>',c.fullname,'</a>') AS "Дисципліна",

(SELECT DISTINCT concat(u.lastname, ' ', u.firstname)

FROM

prefix_role_assignments AS ra

JOIN prefix_user AS u ON ra.userid $=$ u.id

JOIN prefix_context AS ctx ON ctx.id $=$ ra.contextid

WHERE ra.roleid = 3 AND ctx.instanceid = c.id AND ctx.contextlevel = 50 LIMIT 1) AS "Викладач",

(SELECT Count ${ }^{*}$ ) FROM prefix_question q INNER JOIN prefix_question_categories qc ON qc.id = q.category AND q.qtype <> 'random' AND q.parent = 0 INNER JOIN prefix_context ctx ON ctx.id = qc.contextid WHERE ctx.instanceid = c.id AND ctx.contextlevel $=50)+$

(SELECT Count $\left(^{*}\right)$ FROM \{question\} q INNER JOIN \{question_categories\} qc ON q.category = qc.id AND q.qtype <> 'random' AND q.parent = ' 0 ' INNER JOIN \{context\} ctx ON qc.contextid = ctx.id AND ctx.contextlevel = '70' INNER JOIN \{course_modules\} $\mathrm{cm}$ ON ctx.instanceid $=\mathrm{cm}$.id AND cm.module $=($ SELECT m.id FROM \{modules $\} \mathrm{m}$ WHERE m.name='quiz') WHERE cm.course $=\mathrm{c} . \mathrm{id})$

AS 'Питання ',

(SELECT COUNT ${ }^{*}$ ) FROM prefix_course_modules AS cm INNER JOIN prefix_modules AS $\mathrm{m}$ ON cm.module $=$ m.id WHERE cm. course = c.id AND m.name = 'quiz') AS "Тести",

(SELECT COUNT $\left({ }^{*}\right)$ FROM prefix_course_modules AS cm INNER JOIN prefix_modules AS $\mathrm{m}$ ON cm.module $=$ m.id WHERE $\mathrm{cm}$.course = c.id AND m.name = 'assign') AS "Завдання",

(SELECT COUNT ${ }^{*}$ ) FROM prefix_course_modules AS $\mathrm{cm}$ INNER JOIN prefix_modules AS $\mathrm{m}$ ON cm.module $=$ m.id WHERE $\mathrm{cm}$.course = c.id AND m.name = 'page') AS "Сторінки",

(SELECT COUNT $\left({ }^{*}\right)$ FROM prefix_course_modules AS cm INNER JOIN prefix_modules AS $\mathrm{m}$ ON cm.module $=$ m.id WHERE $\mathrm{cm}$.course = c.id AND m.name = 'resource') AS "Файли",

(SELECT COUNT $\left({ }^{*}\right)$ FROM prefix_course_modules AS $\mathrm{cm}$ INNER JOIN prefix_modules AS $\mathrm{m}$ ON cm.module $=$ m.id WHERE $\mathrm{cm}$.course = c.id AND m.name = 'url') AS "Посилання",

(SELECT COUNT $\left({ }^{*}\right)$ FROM prefix_role_assignments AS ra JOIN prefix_user AS u ON ra.userid $=$ u.id JOIN prefix_context AS ctx ON ctx.id = ra. contextid WHERE ra.roleid $=5$ AND ctx.instanceid = c.id AND ctx.contextlevel = 50 LIMIT 1) AS "Студенти"

FROM 'prefix_course' AS c

JOIN 'prefix_course_categories' AS cc ON cc.id = c.category

WHERE cc.name != 'APXIB'

$\% \%$ FILTER_CATEGORIES:C.category $\% \%$

GROUP BY c.Id

ORDER BY FIELD(cc.id, 2, .. перелік категорій курсів ... , 1, 37) ASC) as Report

WHERE 'Викладач' IS NOT NULL AND 'Питання '+'Тести'+'Завдання'+'Сторінки'+' Файли '+ Посилання'

Pис. 3. Sql-запит аналізу наповнення системи електронними навчальними курсами 
Наведений у роботі приклад sql-запиту може бути адаптовано до потреб будь-якого 3B0, що упроваджує аналогічну систему, і змінено за аналогією для аналізу інших елементів ЕНК. Використання таких запитів дозволяє аналізувати динаміку наповнення ЕНК та створювати звіти на рівні кафедр і всього навчального закладу. Автоматизовані запити дозволяють фільтрувати ЕНК, використовуючи аналіз їх наповнюваності елементами. Унаслідок виконання запиту, наведеного на рис. 3, створюється таблиця чи діаграма з кількістю таких елементів: «Питання», «Тести», «Завдання», «Сторінки», «Файли», «Посилання», «Студенти» для кожного ЕНК. Для періоду упровадження, показаного на діаграмі рис. 2, наведемо у таблиці 1 відповідну загальну динаміку наповнення системи онлайннавчання зазначеними тут складовими елементами ЕНК.

Табл. 1. Динаміка наповнення системи елементами ЕНК на прикладі «krnu.org»

\begin{tabular}{|c|c|c|c|c|c|c|c|}
\hline Дата & Питання & Тести & Завдання & Сторінки & Файли & Посилання & Студенти \\
\hline вересень & 0 & 0 & 0 & 0 & 0 & 0 & 0 \\
\hline жовтень & 12303 & 315 & 44 & 35 & 281 & 72 & 245 \\
\hline листопад & 12303 & 315 & 44 & 35 & 281 & 72 & 245 \\
\hline грудень & 29131 & 595 & 60 & 45 & 389 & 113 & 1177 \\
\hline січень & 30813 & 682 & 60 & 45 & 403 & 161 & 1186 \\
\hline лютий & 41339 & 873 & 68 & 48 & 471 & 219 & 1539 \\
\hline березень & 43591 & 963 & 75 & 48 & 529 & 219 & 1805 \\
\hline квітень & 47321 & 1121 & 83 & 52 & 691 & 232 & 2304 \\
\hline
\end{tabular}

Аналіз динаміки використання елементів ЕНК дозволив з'ясувати, що викладачі під час наповнення навчальними матеріалами віддають перевагу файлам з готовими матеріалами, які $\epsilon$ найбільш ресурсоємними та швидко вичерпують наявний хостінговий простір, що змушує встановлювати обмеження на розмір файлів, що завантажуються. Отже, за результатами аналізу рекомендується використовувати зовнішні репозиторії для збереження фрайлів 3 відповідними посиланнями на їх завантаження. Найменш популярні у викладачів «Сторінки», які потребують створення в онлайн-режимі безпосередньо у системі з використанням онлайн-редактора чи розмітки $\mathrm{html}$, що є складним для непідготовлених користувачів системи.

\section{III Результати}

Для швидкої інтеграції системи в освітній простір закладу вищої освіти запропоновано таку схему взаємодії, як на рис. 4, що уможливило мінімізацію змін функціоналу підрозділів під час упровадження та виконання налаштування системи спільними зусиллями усіх користувачів, незалежно від інших структурних підрозділів.

Запропонована у роботі методика та послідовність упровадження системи онлайн-навчання, створене програмне забезпечення для автоматизації аналізу динаміки наповнення системи електронними навчальними курсами, зібрана статистика та її аналіз дозволили оптимізувати упровадження, скоротити терміни тестування системи та зменшити фінансові витрати на упровадження.

На різних етапах упровадження системи онлайн-навчання [13] у Кременчуцькому національному університеті було проведено опитування учасників системи для з'ясування їx готовності до упровадження та сприйняття нової форми організації навчального процесу. Результати опитування наведено у таблиці 2. Тут «1-й етап» відповідає стану упровадження, коли система була створена, налаштована, а її учасники ознайомлені з можливостями системи та її перевагами та почали нею користуватися (листопад-грудень), «2-й етап» - більшість викладачів створили власні ЕНК у системі та всі учасники опитування випробували її можливості (березень-квітень). Дані у таблиці 2 наведені у відсотках від загальної кількості опитаних. Опитування проводилось анонімно без ідентифікації учасників засобами системи онлайн-навчання. Питання з позначкою (*) передбачало можливість вибору кількох варіантів відповідей, а усі інші - тільки один варіант. 


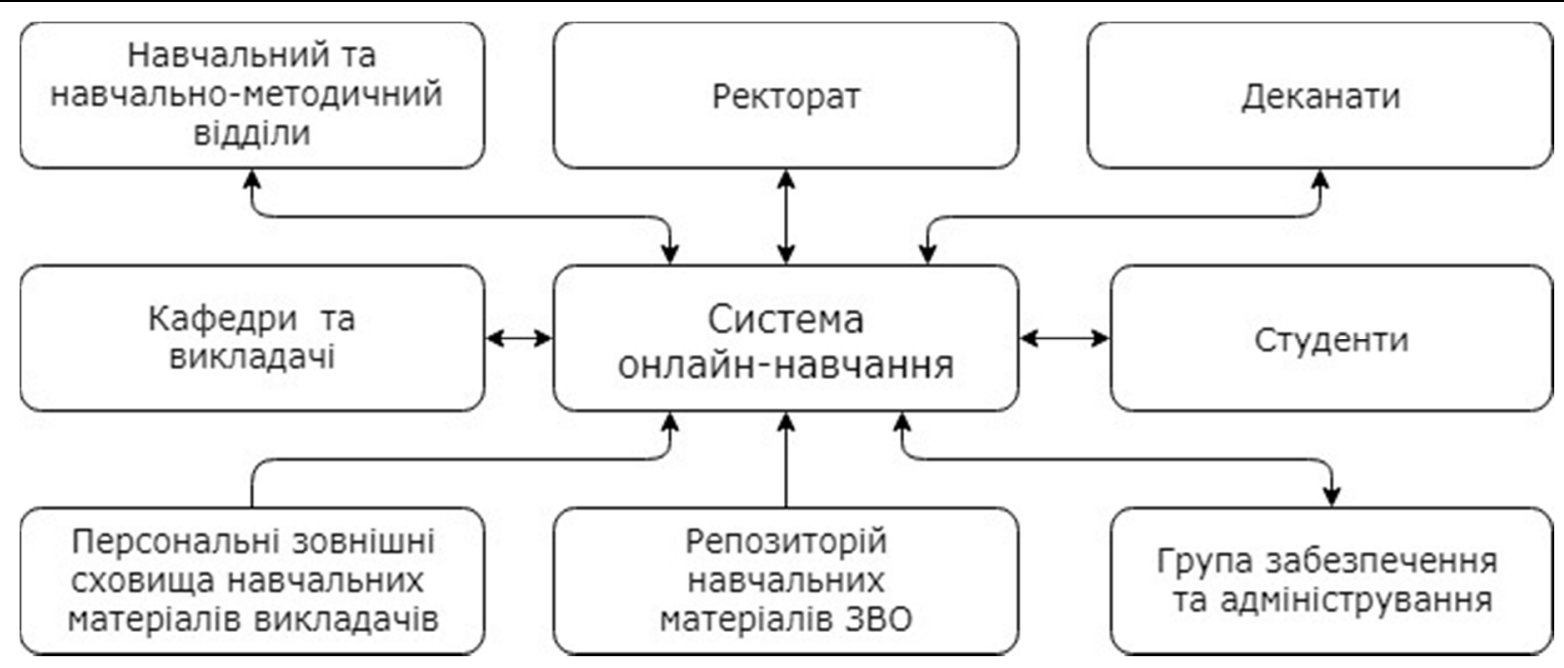

Рис. 4. Структурна схема інтеграції системи онлайн-навчання у ЗВО

Табл. 2. Результати опитування користувачів онлайн-системи на прикладі «krnu.org»

\begin{tabular}{|c|c|c|}
\hline \multirow{2}{*}{$\begin{array}{c}\text { Питання та } \\
\text { варіанти відповіді }\end{array}$} & \multicolumn{2}{|c|}{ Результати опитування } \\
\hline & 1-й етап & 2-й етап \\
\hline \multicolumn{3}{|c|}{ Чи потрібна система онлайн-навчання університету? } \\
\hline Так, безумовно потрібна & $81,4 \%$ & $94,4 \%$ \\
\hline Ні, не потрібна & $12,9 \%$ & $0 \%$ \\
\hline Не визначився(лась) & $5,7 \%$ & $5,6 \%$ \\
\hline \multicolumn{3}{|c|}{ Укажіть зручні для вас способи використання системи (*) } \\
\hline Можливість доступу до навчальних матеріалів & $76,5 \%$ & $88,9 \%$ \\
\hline Можливість онлайн-консультацій & $38,2 \%$ & $44,4 \%$ \\
\hline Проведення (проходження) онлайн тестування & $69,1 \%$ & $77,8 \%$ \\
\hline Онлайн здавання та перевірка завдань & $66,2 \%$ & $83,3 \%$ \\
\hline Електронні журнали відвідування занять та оцінювання & $44,1 \%$ & $55,6 \%$ \\
\hline Контроль та організація самостійної роботи & $39,7 \%$ & $55,6 \%$ \\
\hline Інше & $7,4 \%$ & $5,6 \%$ \\
\hline \multicolumn{3}{|c|}{ Чи сприятиме онлайн система покращенню якості навчання? } \\
\hline Так, однозначно & $66,7 \%$ & $66,7 \%$ \\
\hline Ні, не сприятиме & $20,3 \%$ & $22,2 \%$ \\
\hline Не визначився(лась) & $13 \%$ & $11,1 \%$ \\
\hline \multicolumn{3}{|c|}{ Загальна оцінка системи (ффункціональність, дизайн, зручність) } \\
\hline Оцінка «1»-дуже погано & $10 \%$ & $0 \%$ \\
\hline Оцінка «2»- погано & $7,1 \%$ & $5,6 \%$ \\
\hline Оцінка «3» - задовільно & $17,1 \%$ & $27,8 \%$ \\
\hline Оцінка «4»-добре & $41,4 \%$ & $11,1 \%$ \\
\hline Оцінка «5»- відмінно & $24,3 \%$ & $55,6 \%$ \\
\hline \multicolumn{3}{|l|}{ Xmo ви? } \\
\hline Викладач & $30 \%$ & $33,3 \%$ \\
\hline Студент & $65,7 \%$ & $66,7 \%$ \\
\hline Випадковий відвідувач & $4,3 \%$ & $0 \%$ \\
\hline
\end{tabular}


Аналіз результатів опитування показує, що використання системи у реальних умовах та отриманий досвід змінює ставлення до неї учасників і надає розуміння про можливі варіанти використання. Результати опитування показали, що користувачі насамперед оцінили можливості використання системи для зручного забезпечення студентів навчальними матеріалами та можливість проведення тестування, та здавання і оцінювання виконаних робіт онлайн.

\section{IV Обговорення}

Модульна структура Moodle, побудованої на основі плагінів, дозволяє на початковому етапі упровадження створити мінімальну конфігурацію системи та розширювати її можливості поступово за потреби. Саме це спрощує адаптацію викладачів до керування власними ЕНК і користування онлайнсистемою, не відволікаючи їх на різноманіття зайвих налаштувань. Набутий досвід дозволяє авторам рекомендувати послідовне упровадження функціоналу системи на платформі Moodle. Моніторинг уподобань викладачів під час упровадження завдяки розробленим кодам запитів дозволяє розробникам системи спрямовувати зусилля на розвиток найбільш затребуваного функціоналу, адаптуючи можливості системи до потреб конкретної спільноти користувачів. Конфігурація плагінів Moodle-системи залежить від переліку ЕНК, що додаються до системи. Наприклад, ЕНК математичного спрямування потребують установлення онлайн-редакторів для набору математичних формул, а ЕНК з хімії чи біології - редакторів для набору хімічних формул. Також ЕНК впливають і на типи тестових питань, яким викладачі надають перевагу під час складання тестів. Розробникам системи онлайн-навчання потрібно враховувати це конфігуруючи структуру системи онлайн-навчання. Установлювати усі можливі варіанти плагінів недоцільно, оскільки це переобтяжує систему, ускладнює ї̈ використання, уповільнює, зменшує надійність.

Статистичний аналіз даних моніторингу активності користувачів системи онлайн-навчання дозволяє стверджувати, що тільки приблизно 20\% викладачів використовують до $80 \%$ функціонала системи та створюють близько 80\% контенту навчальних матеріалів, що відповідає розподілу Паретто. Переважно такий розподіл обумовлений рівнем комп'ютерної підготовки викладачів і усвідомленням ними можливостей використання системи онлайн-навчання для викладання конкретних навчальних дисциплін. Тому розробникам систем онлайн-навчання немає сенсу збільшувати можливості системи, не змінивши відсотки такого розподілу завдяки проведенню практичних занять з викладачами для отримання ними відповідних компетенцій. Під час таких занять слід приділяти увагу й психологічним аспектам через побоювання викладачів виглядати некомпетентними у очах своїх студентів, яким інколи простіше опановувати комп'ютерні технології, ніж викладачам. Також під час упровадження систем онлайн-навчання слід ураховувати віковий розподіл викладацького складу у 3ВО, що теж впливає на швидкість опанування новітнім програмним забезпеченням для створення ЕНК.

Інша проблема, виявлена під час використання системи онлайн-навчання, що потребує подальшого вивчення, полягає у тому, що змінюється розподіл часу, який витрачає викладач на підготовку ЕНК. Безумовно, створення повноцінного ЕНК курсу, який упроваджується уперше, потребує для підготовки значно більше зусиль і часу, ніж для звичайного курсу. Викладач може очікувати на компенсацію цих витрат у разу повторного та багаторазового використання ЕНК у наступних семестрах та унаслідок зменшення часових витрат на видачу навчальних матеріалів і перевірку завдань, задач, тестів. Проблема вимірювання часових витрат, а унаслідок цього і фрінансових, на створення ЕНК досліджувалась у роботах $[16,17]$, але до сьогодні ще не існує усталених методик. Можна тільки рекомендувати створювати у першу чергу ті ЕНК, які будуть неодноразово використовуватися викладачем або потребують значних витрат на перевірку завдань і розраховані на викладання для декількох груп студентів.

Наявна іще одна проблема - опанування викладачами нових методик проведення навчальних занять з використанням інформаційно-медійних технологій, що використовуються у системах онлайннавчання. Наприклад, студент отримує доступ до електронних матеріалів лекцій та втрачає потребу писати конспекти, і з'являється можливість інтерактивної взаємодії студента з навчальним матеріалом, виконання онлайн вправ, можливість демонстрації відео- та медійних навчальних матеріалів. 3 одного боку, це урізноманітнює вміст навчальних матеріалів, а з іншого боку, збільшує інформаційне навантаження студента. Методики викладання з використанням інформаційно-медійних технологій 
досліджували Бріскін Ю.А., Полат Є.С., Собаєва О.В., Бєляєва Н.В. та інші. Але ці дослідження потребують подальшого розвитку через постійне удосконалення можливостей зазначених технологій. Наприклад, y Moodle з'являються нові плагіни, які дозволяють використовувати нові типи тестів і форми проведення онлайн-занять. Кількість таких нових плагінів, які можуть впливати на організацію навчання та методики подання навчального матеріалу обчислюється не одним десятком на рік, що надає викладачу простір для творчості. Отже можна стверджувати, що розвиток інформаційно-медійних технологій сприяє упровадженню новітніх методик у навчальний процес, дозволяє використовувати нові форми та способи подання навчального матеріалу, а створена у ЗВО система онлайн-навчання потребує супроводження, постійного оновлення та навчання іїі користувачів.

\section{V Висновки}

Запропонована у роботі методика упровадження системи онлайн-навчання знайшла своє практичне втілення апробована під час розробки системи «krnu.org» для Кременчуцького національного університету імені Михайла Остроградського, а отриманий досвід та аналіз накопичених даних дозволяє зробити такі висновки:

- модульна структура Moodle дозволяє оптимізувати процес упровадження системи онлайннавчання, ураховувати уподобання користувачів, збирати статистичні дані про їх активність і використовувати їх для визначення стратегії подальшого розвитку системи;

- упровадження слід починати з мінімальної конфігурацією системи, аби викладачі мали можливість зосередитися на певних елементах ЕНК, наприклад, на створенні тестових завдань;

- головною проблемою упровадження системи онлайн-навчання слід вважати рівень знань викладачів та необхідність організації їх навчання за двома напрямками: підвищення загального рівня користування можливостями інформаційно-медійних технологій та опанування методиками їх використання у навчальному процесі;

- використання системи онлайн-навчання у ЗВО потребує зміни методик в організації навчального процесу та низки нормативних документів.

Упровадження системи онлайн-навчання в освітній простір 3ВО сприяє покращенню моніторингу якості викладання, дозволяє скоротити витрати на комплектування навчальних лабораторій та комп'ютерних класів обчислювальною технікою та програмним забезпеченням оскільки надає можливість використання учасниками навчання власних мобільних пристроїв (смартфонів, планшетів, ноутбуків), надає можливості для упровадження інклюзивної освіти.

Досвід упровадження системи-онлайн навчання, поданий у даній статі, сприятиме подальшому упровадженню новітніх інформаційних технологій у навчальний освітній простір закладів вищої освіти, визначить пріоритети та наявні проблеми і способи їх подолання.

\section{Бібліографрічні посилання}

[1] Serhiienko S. Innovative Technologies in Laboratory Workshop for Students of Technical Specialties/ M. Zagirnyak, S. Serhiienko, O. Chornyi // Proceedings of 2017 IEEE First Ukraine Conference on Electrical and Computer Engineering (UKRCON). Kyiv, Ukraine, 2017. P. 1216-1220. IEEE Catalog Number: CFP17K03-USB.

[2] Славко Г.В. Розробка та впровадження інтерактивної перевірки програмних кодів у системі онлайн-освіти "Математика.укр" [Електронний ресурс] / Інформатика та системні науки. 2017. URL: http://dspace.puet.edu.ua/bitstream/123456789/5552/1/22\%20Славко.pdf. (дата звернення 04.03.2019).

[3] Система онлайн освіти "Математика.укр" [Електронний ресурс] - Режим доступу до ресурсу: http://математика.укр.

[4] Вембер В. П. Інформатизація освіти та проблеми впровадження педагогічних програмних засобів в навчальний процес I Інформаційні технології і засоби навчання, 2007. Том 3. №2 URL: https://journal.iitta.gov.ua/index.php/itt//article/view/262 (дата звернення: 20.03.2019).

[5] Гончарова О. М. Інформатизація освіти як пріоритетний напрямок модернізації освіти в умовах інформаційного суспільства / Проблеми сучасної педагогічної освіти. Ялта: РВВ КДГІ, 2005. Вип.7. Ч.1. С. 59-64.

[6] Кремень В. Г. Інформатизація освіти - провідний напрям підвищення результативності навчального процесу / Комп' ю-тер у школі та сім' ї, 2011. Вип. 1. С. 3-6.

[7] Осадчий В. В. Педагогічні засади професійного консультування молоді засобами Інтернет: дис. ... канд. пед. наук: 13.00.04; Інститут педагогіки і психології професійної освіти АПН України. К., 2005. 213 с.

[8] Рамський Ю. С. Інформаційне суспільство. Інформатизація освіти / Комп'ютерно-орієнтовані системи навчання: $з б$. наук. праць. К.: НПУ ім. МП Драгоманова, 2003. Вип. 7. С. 16-28. 
[9] Биков В. Ю. Хмарна комп'ютерно-технологічна платформа відкритої освіти та відповідний розвиток організаційнотехнологічної будови IT-підрозділів навчальних закладів / Теорія і практика управління соціальними системами: філососрія, психологія, педагогіка, соціологія. Харків: НТУ "ХПІ", 2013. № 1. С. 81-98.

[10] Коврижкін О. Г. Проблема інформатизації адміністративних процесів в навчальних закладах / Комп'ютерноорієнтовані системи навчання. К: НПУ ім. М.П. Драгоманова, 2001. Вип. 4. С. 139-143.

[11] Мокін Б. І., Грабко В. В., Месюра В. І., Юхимчук С. В. Досвід використання інтернет-технологій у Вінницькому державному технічному університеті / Вінницький державний технічний університет. URL: http://vntu.edu. ua/ies2000/doclad/a/a03.htm (дата звернення 04.03.2019).

[12] Адамова І. 3., Уграк М. І. Використання Інтернет-технологій у навчальному процесі //Вісник Чернівецького торговельно-економічного інституту. Економічні науки. 2014. №. 1. С. 374-379.

[13] Система онлайн-навчання. KpHY URL: http://krnu.org. (дата звернення 04.03.2019).

[14] LMS Moodle. URL: http://moodle.org. (дата звернення 04.03.2019).

[15] Славко Г. В., Решетило В. В., Шевченко С. В. Розробка та інтеграція плагінів математичного спрямування у систему дистанційної освіти Moodle / Вісник Кременчуцького національного університету імені Михайла Остроградського. 2017. Вип. 2(1). С. 48-53.

[16] Седун А. М., Горбачева В. А. Обоснование стоимости дистанционного обучения в вузе / Вестн. БГЭУ. 2010. № 6. C. 53-61.

[17] Ernst Z Rothkopf, Costs of asynchronous distance ventures, Economics of Education Review, Volume 22, Issue 4, 2003, Pages 439-443.

\section{References}

[1] Zagirnyak, M., Serhiienko, S., Chornyi, O. (2017). Innovative Technologies in Laboratory Workshop for Students of Technical Specialties/ // Proceedings of 2017 IEEE First Ukraine Conference on Electrical and Computer Engineering (UKRCON). Kyiv, Ukraine,. P. 1216-1220. IEEE Catalog Number: CFP17K03-USB.

[2] Slavko, H. V. (2017). Rozrobka ta vprovadzhennya interaktyvnoyi perevirky prohramnykh kodiv u systemi onlayn-osvity "Математика.укр" $\quad$ / Informatyka $\quad$ ta $\quad$ systemni http://dspace.puet.edu.ua/bitstream/123456789/5552/1/22\%20Славко.pdf (accessed 04.03.2019). [in Ukrainian]

[3] Systema onlayn osvity "Математика.укр" URL: http://математика.укр. (accessed 04.03.2019). [in Ukrainian]

[4] Vember, V. P. (2007), Informatyzatsiia osvity ta problemy vprovadzhennia pedahohichnykh prohramnykh zasobiv v navchalnyi protses. available / Informatsiini tekhnolohii i zasoby navchannia, Vol. 3. №2. URL: https://journal.iitta.gov.ua/index.php/itt// article/view/262 (accessed 20.03.2019). [in Ukrainian]

[5] Goncharova, O. M. (2005). Informatyzatsiia osvity yak priorytetnyi napriamok modernizatsii osvity v umovakh informatsiinoho suspilstva. Problemy suchasnoi pedahohichnoi osvity, Yalta, Iss. 7, Part 1, pp. 59-64. [in Ukrainian]

[6] Kremen, V. G. (2011). Informatyzatsiia osvity - providnyi napriam pidvyshchennia rezultatyvnosti navchalnoho protsesu. Komp' yuter u shkoli ta sim' yi, Iss. 1. pp. 3-6. [in Ukrainian]

[7] Osadchiy, V. V. (2005). Pedahohichni zasady profesiinoho konsultuvannia molodi zasobamy Internet [Pedagogical bases of professional consulting of young people by Internet facilities] (Dys. kand. ped. nauk), Institute of pedagogy and psychology of vocational education Academy of Pedagogical Sciences of Ukraine, Kyiv. [in Ukrainian]

[8] Ramsky, Yu. S. (2003). Informatsiine suspilstvo. Informatyzatsiia osvity / Kompiuterno-oriientovani systemy navchannia, NPU after M.P. Drahomanov, Kyiv, Iss. 7, pp. 16-28. [in Ukrainian]

[9] Bykov, V. lu. (2013). Khmarna kompiuterno-tekhnolohichna platforma vidkrytoi osvity ta vidpovidnyi rozvytok orhanizatsiinotekhnolohichnoi budovy IT-pidrozdiliv navchalnykh zakladiv. Teoriia i praktyka upravlinnia sotsialnymy systemamy: filosofiia, psykholohiia, pedahohika, sotsiolohiia, Kharkiv, NTU "KhPI", Iss. 1, pp. 81-98. [in Ukrainian]

[10] Kovryzhkin, O. G. (2001). Problema informatyzatsii administratyvnykh protsesiv v navchalnykh zakladakh / Kompiuternooriientovani systemy navchannia, NPU after M.P. Drahomanov, Kyiv, Iss. 4, pp. 139-143. [in Ukrainian]

[11] Mokin, B. I., Hrabko, V. V., Mesyura, V. I., Yukhymchuk, S. V. (2000). Dosvid vykorystannya internet-tekhnolohiy u Vinnyts'komu derzhavnomu tekhnichnomu universyteti / Vinnyts'kyy derzhavnyy tekhnichnyy universytet. URL: http://vntu.edu.ua/ies2000/doclad/a/a03.htm. [in Ukrainian]

[12] Adamova, I. Z., Uhrak, M. I. (2014). Vykorystannya Internet-tekhnolohiy u navchal'nomu protsesi // Visnyk Chernivets'koho torhovel'no-ekonomichnoho instytutu. Ekonomichni nauky. Iss. 1. pp. 374-379. [in Ukrainian]

[13] Systema onlayn-navchannya KrNU. URL: http://krnu.org. (accessed 04.03.2019). [in Ukrainian]

[14] LMS Moodle. URL: http://moodle.org (accessed 04.03.2019).

[15] Slavko, H. V., Reshetylo, V. V., Shevchenko, S. V. (2017). Rozrobka ta intehratsiya plahiniv matematychnoho spryamuvannya u systemu dystantsiynoyi osvity Moodle. Visnyk Kremenchuts'koho natsional'noho universytetu imeni Mykhayla Ostrohrads'koho. Iss. 2(1). pp. 48-53. [in Ukrainian]

[16] Sedun, A. M., Gorbacheva, V. A. (2010). Obosnovaniye stoimosti distantsionnogo obucheniya v vuze. Vestnik BGEU. Iss. 6. pp. 53-61. [in Russian]

[17] Ernst, Z. Rothkopf (2003). Costs of asynchronous distance ventures, Economics of Education Review, Volume 22 , Issue 4. pp. 439-443. 


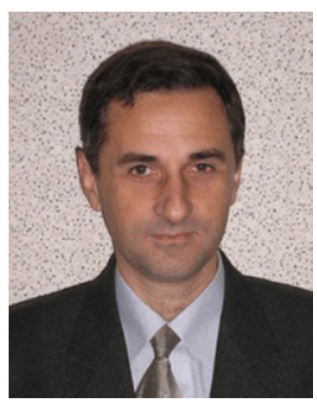

\section{Славко Геннадій Володимирович,}

к.Т.н., доцент, заступник директора навчально-наукового інституту механіки і транспорту, доцент кафедри «Інформатика і вища математика»,

Кременчуцький національний університет імені Михайла Остроградського,

вул. Першотравнева, 20, м. Кременчук Полтавської обл., Україна, 39600..

Тел. +38(05366)-3-21-01, E-mail: krnu@i.ua

\section{Slavko Gennadii Volodymyrovych,}

Ph.D., associate professor, deputy director of the Educational and Scientific Institute of Mechanics and Transport, associate professor of the department "Informatics and Higher Mathematics",

Kremenchuk Mykhailo Ostrohradskyi National University,

vul. Pershotravneva, 20, Kremenchuk, Poltava Region, Ukraine.

Tel. +38(05366)-3-21-01. E-mail: krnu@i.ua

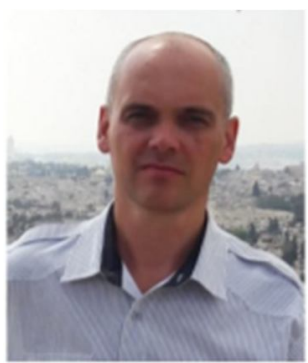

\section{Сергієнко Сергій Анатолійович,}

к.т.Н., доцент, проректор з науково-педагогічної роботи і новітніх технологій в освіті, доцент кафедри «Системи автоматичного управління та електропривод»,

Кременчуцький національний університет імені Михайла Остроградського,

вул. Першотравнева, 20, м. Кременчук Полтавської обл., Україна, 39600.

Тел. +380984334771, E-mail: sergsa@kdu.edu.ua

\section{Serhiienko Serhii Anatoliiovych,}

Cand.Sc. (Eng.), Associate Professor, Pro-rector, Associate Professor of Automatic Control Systems and

Electric Drive Department,

Kremenchuk Mykhailo Ostrohradskyi National University,

vul. Pershotravneva, 20, Kremenchuk, Poltava Region, Ukraine.

Tel. +380984334771 E-mail: sergsa@kdu.edu.ua

ORCID: https://orcid.org/0000-0002-3977-5239

Researcher ID: 0-6912-2018

Scopus ID: 57196471214

\section{Citation (APA):}

Slavko, G., Serhiienko, S. (2019). Experience of applying and integrating of the online education system on a base of Moodle platform into the university's educational environment. Engineering and Educational Technologies, 7 (2), 126-136. doi:

https://doi.org/10.30929/2307-9770.2019.07.02.13

\section{Цитування (ДСТУ 8302:2015):}

Славко Г. В., Сергієнко С. А. Досвід упровадження та інтеграції системи онлайн-навчання на платформі Moodle у освітній простір університету / Інженерні та освітні технології. 2019. Т. 7. № 2. С. 126-136. doi: https://doi.org/10.30929/23079770.2019 .07 .02 .13

Обсяг статmі: сторінок-11 ; умовних друк. аркушів - 1,593. 